\title{
Founders' Note
}

\section{The Parish Review}

\author{
Ruben Borg \\ The Hebrew University of Jerusalem \\ Paul Fagan \\ University of Vienna
}

In his 28 December 1944 column - flanked on one side by 'The German Offensive' (on the eerie silence surrounding events on the Western front), on the other by 'The Dublin Dog Show' (victorious: cocker spaniel 'Ardent Lass') - Myles na gCopaleen laments:

How well the crowd in this town would never think of forming a M. na gC. Society! It'd be such a . . . a . . . f fine tribute to an old man! And with a statue in College Green, my back turned to Trinity! (I still may have the figure to wear a stone beard and stone frock coat). ${ }^{1}$

The complaint was levied in response to a recently published report in The Irish Times: at a Dublin meeting of the George Bernard Shaw Society, the idea had been floated that 'If Plato had been the Colossus of the ancient world of thought, Shaw was the Colossus of the modern world...' Myles's objection? 'Not a word about me in the whole thing from beginning to end! (! ! ).'

Whether writing under the guise of Flann O'Brien or Myles na gCopaleen, Brian O'Nolan always insisted upon a comically outsized view of his own importance to world literature - indeed, in an even grander view, to the general 'scheme of things.' Recently, however, circumstances have conspired to make him, of all things, a man of his word. We find ourselves at the point at which Brian/Flann/Myles, et al. have finally entered the larger critical and pop-cultural consciousness. O'Nolan's influence on the contours of $20^{\text {th }}$-century fiction is now widely acknowledged, his name increasingly an essential reference point when discussion turns to the works of Jorge Luis Borges or Vladimir Nabokov, or to modern metafictional and (post)modern staples such as David Foster Wallace's Infinite Jest, Mark Z. Danielewski's House of Leaves, or Italo Calvino's If on a winter's night a traveler. Most recently, O'Nolan's centenary year encouraged the world at large to take stock of how his legacy has been shaped throughout the last century - particularly in comparison with his exiled, and significantly more canonised, compatriots Joyce and Beckett - and to chart how his 
literary reputation has gathered momentum over the last decades. It is a strange reputation indeed. Long considered one of the best kept secrets of modern literature (by authorities as varied as Anthony Burgess, Graham Greene, and Jorge Luis Borges), the author of At Swim- Two-Birds, The Third Policeman, and An Béal Bocht combines the tags of 'incomparable comic genius' and 'avant-garde innovator' with that of 'wasted talent.'

So, given all this growing evidence that Myles might indeed be that very thing, 'the Colossus of the modern world,' it is surely high time to follow the advice of the man himself and establish the M. na gC. Society! (And while we can't yet unveil the 'statue in College Green,' there are various forces at work to ensure this next step in Myles's escalating bid for world domination - see the Letters to the Editor section on The Flann O'Brien Statue Campaign in the present issue). Which means that this note is also intended as a performative gesture: we are henceforth, quite officially, and to the full satisfaction of the law, The International Flann O'Brien Society.

There might seem to The Plain People of Ireland to be good reasons not to set up such a society dedicated to the academic and scholarly study of O'Nolan's works. One can easily imagine, during an excruciatingly long wait for a bus, being accosted by The Brother's brother: 'Sure man, why would you want to do a thing like that? Sure, isn't the whole thing only a laugh man?' Indeed, one would not have to read many pages of Cruiskeen Lawn to hear this argument echoed by Myles himself. For example:

Charlie Chaplin was once a great clown. In the twenties I was laughing myself (sic) at his jerky funniness. He was good. He was a terrible hard case - but the lower-cases ('film art: an international review of advance guard cinema') found him out. One day some toad - some velveteened work-shy 'marxist' toad sternly reproved people for laughing at Mister Chaplin. 'Do you not see, old boy, thet in Chaplin we hev an expression on the highest artistic plain of all our pathetic human striving. I mean the pursuit of heppiness and all thet, our poor frustrated human nature. The little tremp, I mean, is you and I. Chaplin is a great artist, I mean. You mustn't loff, you know (...)' And poor Chaplin, a simple soul if ever there was one, gets to hear this chat and makes The Great Dictator. ${ }^{2}$

While it would tin-eared to take unseriously Myles's beef with those 'lower-cases' who would scold anyone enjoying the gag for 'not getting it,' it is equally tin-eared to assign these views unreflectively to his creator - to forget that Myles na gCopaleen is a comic invention, perhaps O'Nolan's greatest, that allowed him to explore a particular kind of acerbic comic tension grounded in the contradictory and po-faced discourses about Irish cultural politics that surrounded him. Just as the sublime and the ridiculous 
constantly threaten to subvert each other in The Third Policeman, so Myles assumes a range of different voices and contradictory positions - intellectual and antiintellectual, populist and elitist - while always subtly turning his sights on himself and his own soapbox. It is our belief that a true Flann $\mathrm{O}^{\prime}$ Brien studies worthy of that name will demonstrate the responsiveness of his far-reaching body of work across genres and media to diverse theoretical, critical, and historical frameworks, while also foregrounding a close attention to the comic spirit and precise modulation of tone that animates his best writing. We remain undiscouraged, in any case, by the high likelihood that a real M. na G. Society and journal would be lambasted from Cruiskeen Lawn as the conspiracy of WAAMA and the Corduroys.

A second potential objection might focus on the 'International' part of the equation, as an echo of the critical commonplace $\mathrm{O}^{\prime}$ Nolan is not an international writer, that his writing is, in Hugh Kenner's terms, 'not bottled for export.' ${ }^{3}$ The argument is mostly attributable, it seems, to the fact that unlike Joyce and Beckett, O'Nolan rarely set foot outside of Ireland - excepting, of course, the report of the perhaps overly credulous Time magazine, who faithfully reported in a 1943 piece that O'Nolan had briefly travelled to Germany in 1933. (During this trip, O'Nolan was supposedly 'beaten up and bounced out of a beer hall for uncomplimentary references to Adolf Hitler' and married Clara Ungerland, the 18-year-old daughter of a Cologne basketweaver, a wife who, like so many of Flann's female characters, disappeared only a month after the wedding from 'galloping consumption.'4) Frank McNally evocatively captures the commonplace of O'Nolan's role as the stay-at-home husband of Irish literature:

If modern Irish literature is a three-pin plug (and why not?) Joyce and Beckett were the live and neutral prongs, whereas O'Nolan was the earth - staying at home, working a day job while writing neglected masterpieces by night, and frequently mocking the pretensions of Ireland's famous exiles (especially Joyce), who suffered for their art in Paris. ${ }^{5}$

While there is a truth to this conceit that any consideration of O'Nolan's writings would be ill-advised to ignore, there's also something queer in the notion that authors might only be read in the countries to which they travelled corporally within their lifetimes - Joyce, for example, never set foot in America and just look how that has turned out.

Moreover, there is within the idea a sub-claim that while Joyce's great metafictional and modernist - or, depending on taste, post-modernist - books about colonial and post-colonial Dublin are best explored by an international community, 
O'Nolan's great metafictional and modernist - or, depending on taste, post-modernist - books about colonial and post-colonial Dublin are best understood by the local crowd. We believe this is neither prejudice nor double standard. The constant comparisons with Joyce, the international Irishman par excellence, had long been a conditioned reflex of $\mathrm{O}^{\prime}$ Nolan criticism. And inevitable as they are, these comparisons always serve to emphasise Our Man's parochial status. But what if O'Nolan's parochialism was in fact, perversely, the hallmark of his literary genius? By which we mean not a closed, exclusionary resistance to the global, cosmopolitan outlooks that characterised art and politics in the $20^{\text {th }}$ century; rather a literary vision that dares us to explore the currency - possibly, the universal appeal - of what remains irreducibly local in any culture (idiom, accent, humour, barroom politics). A parochialism for the modern world. In his Flann O'Brien: A Portrait of the Artist as a Young Post-Modernist, Keith Hopper, for instance, details the complexity of O'Nolan's satirical, oppositional stance towards both of the reigning grand-narratives of Irish literature: the "Two Towers' of Yeats's reactionary Celtic turn and Joyce's counter-turn towards Europe and modernity. ${ }^{6}$ Irreducible to a single ideological position, O'Nolan's writing requires a diverse set of historical perspectives, theoretical frameworks, and analytical tools to situate it more precisely within these overlapping contexts and drives - internationalism and localism, the avant-garde and the popular, civic-mindedness and ironic detachment. It is in the spirit of capturing these conflicts in O'Nolan's reception and scholarship and submitting them to a new set of critical stances and inquiries, that we are launching The Parish Review.

That all sounds very fine, our friend at the bus stop might say, but why do we need a society - an international one no less - to hear the many voices of Myles? First and foremost, we are fans, and as fans, we seek the comfort and reassurance of likeminded company. In the broader sense, however, it had always seemed to us, from conversations we had shared with scholars and friends, in QEA sessions and over drinks at various Irish studies and modernism conferences, that there is a vibrant yet unconnected community of international Flanneurs just waiting to emerge. But communities need reasons to get together, and to test this hypothesis we announced 100 Myles, an International Flann O'Brien Conference in Vienna, to take place in the summer of O'Nolan's centenary year. (Although perhaps the location was not so out there: that old gentleman scholar Brother Barnabas had himself taken time out of his busy schedule at Blather to travel to Vienna to 'dog whip' Der Grosse Kaiser Wilhelm demonstrating once again how international and local regions and limits are continuously blurred in O'Nolan's literary imagination). Fittingly, perhaps, the idea for this conference had two points of origin, both pubs: in a smoky Keller during the 2010 James Joyce Symposium in Prague, and at the Universitätsbräuhaus on the 
Vienna campus, in collusion with Werner Huber, head of the Centre for Irish Studies at the Vienna English Department.

As it transpired, strange enlightenments are indeed vouchsafed to those who seek the higher places, with almost a hundred scholars, authors, artists, performers, and $\mathrm{O}^{\prime}$ Nolan enthusiasts (the so-called 'Flannoraks') travelling to Vienna from all over the world to analyse O'Nolan's place among Borges, Calvino, and Nabokov, Kundera, Diderot, and Bolaño. The vibrancy of this emergent, invisible community of O'Nolan enthusiasts and scholars was further confirmed by a number of centenary conferences across the world - brilliantly organised and hosted by Carol Taaffe and Eibhlin Evans in Trinity College Dublin, by Neil Murphy in Nanyang Singapore, and by the John Hume Institute for Global Irish Studies in Sydney. You will find reports and pictures from Vienna and Sydney in the present issue (with Dublin and Nanyang to come in the Winter issue). We hope they will communicate the great deal of excitement that is currently being felt at the emergence of a truly international Flann Studies movement, as well as the invigorating and varied work being undertaken in Flann studies across the world, as O'Nolan's broader canon is explored as a fertile ground for a range of critical perspectives, from cultural materialism, queer theory, and gender studies, to metafiction, genre theory, and deconstruction. Beyond the great array of research on display that week in Vienna, however, there was a second conversation going on, between the pints and papers, about how we are to move forward and capture this moment of centennial interest in Flann. Brendan Gleeson's forthcoming all-star adaptation of At Swim-Two-Birds (the second adaptation, after Kurt Palm's Germanlanguage Austrian film In Schwimmen-Zwei-Vögel), for example, further testifies to O'Nolan's growing cultural purchase and promises that new audiences will continue to discover his work. The question before us was whether we allow the moment to subside or we use it to spearhead a more integrated international community dedicated to this writer.

Well, now that the dust has settled, and we are all back to our exciting routines, it is time to follow through on a few ideas that were floated during that week in Vienna on how to keep the community moving forward, all under the umbrella of the newly minted International Flann O'Brien Society. For the moment, the aims of the society are modest: we want to provide $\mathrm{O}^{\prime}$ Nolan scholars with the means of keeping in touch and staying up to date with the latest $\mathrm{O}^{\prime}$ Nolan-related research worldwide. To this end we have re-opened our 100 Myles site with a new section called '100 Myles... and counting' - you will find us at https://www.univie.ac.at/flannobrien2011/IFOBS.html. We hope that the site will serve as a home address and meeting point for $\mathrm{O}^{\prime}$ Nolan scholars. On the site you will find a news section, a database of member contact details, and our first attempt at a comprehensive Brian O'Nolan bibliography. We intend this to be a 
live and continually updated bibliography of all works, translations, and adaptations by and about Our Man. Please take a spare moment to peruse it and let us know if you see any articles by yourself or others missing, and we will update it as we receive them.

Secondly, we have established this bi-annual IFOBS circular, The Parish Review. Beyond the reports already mentioned, other initiatives in this inaugural issue include two yearly prizes to be known as The Father Kurt Fahrt, S.J. Memorial Prize: one for the 'best book-length publication on a Brian O'Nolan theme' (the Big Fahrt) and one for the 'best essay- length publication on a Brian O'Nolan theme' (the Small Fahrt); a book- review section, and a checklist of Flann scholarship. In future editions we plans to use the Review to shed light on and help access to important O'Nolan-related academic resources, including attempts to piece together $\mathrm{O}^{\prime}$ Nolan's personal library at the time of his death, his UCD Calendar, and the holdings of Special Brian O'Nolan Collections in the Morris Library (Southern Illinois University at Carbondale), Harry Ransom Humanities Research Center (University of Texas), John J. Burns Library (Boston College) and the Niall Montgomery and Timothy O'Keefe collections at the National Library of Ireland. These vast and largely under-analysed collections of O'Nolan's manuscripts and drafts have recently given rise to an emerging field of $\mathrm{O}^{\prime}$ Nolan genetic criticism, and we hope to use future issues to help encourage further research in this direction.

One of the most rewarding aspects of the centenary year was the long line of artists, filmmakers, performers, and musicians who travelled to Vienna and beyond to perform or exhibit their myriad creative and fascinating adaptations and interpretations of O'Nolan's texts. In an attempt to recapture how the creative community's many engagements with Flann's canon can help us to see these texts anew - and to encourage closer ties between the creative and academic Flann communities - we have included a section in The Parish Review for 'Adaptations of Flann.' In this issue you will read reports by Kevin Atherton, the curator of the art exhibition Myles Away from Illustration: The Influence of Flann O'Brien on the Visual Arts and Ergo Phizmiz on adapting The Third Policeman as a steampunk opera. Berlin-based artist David O'Kane was also among those artists in attendance at the Vienna conference, where he screened his short film Babble (for more details see the Vienna report in the present number). David has provided the beautiful cover artwork for this issue, for which the editors are most grateful. As we said, communities need a reason to get together, and the final aim of the nascent IFOBS is to create a framework that will promote and encourage the organisation of future events dedicated to O'Nolan's life and writing. In this regard we are delighted to be able to announce the II International Flann O'Brien Conference 'Problems With Authority,' to take place in Rome 19-21 June 2013 - we look forward to seeing you all there. 
In his closing address at 100 Myles, Anthony Cronin highlighted that every time the publishers tried to bury Brian O'Nolan, it was his readers that brought him back to life - a powerful point on both the strength and durability of O'Nolan's works and on the meaningful role they play in the lives of his devotional legion of readers. We hope that The Parish Review can serve as a site of many further such revivals, and as a home for his most ardent and devoted readers for many years to come...

\section{Notes $\mathcal{E}$ references}

1 Myles na gCopaleen, Cruiskeen Lawn, The Irish Times (28 December 1944): 3.

2 The Best of Myles, ed. Kevin O' Nolan (London: Picador, 1977), 230.

${ }^{3}$ Hugh Kenner, 'The Mocker,' in A Colder Eye: The Modern Irish Writers (New York: Knopf, 1983 ), 262.

${ }^{4}$ Anon. [Stanford Lee Cooper], 'Eire's Columnist,' Time no. 8, 23 August 1943, pp. 30-31

${ }^{5}$ Frank McNally, 'An Irishman's Diary,' The Irish Times, 21 July 2011.

${ }^{6}$ Keith Hopper, Flann O'Brien: A Portrait of the Artist a Young Post-Modernist (Cork: Cork University Press, 2009), 23, 47. 